\title{
O DIREITO AO CONHECIMENTO DA ORIGEM GENÉTICA EM FACE DA INSEMINAÇÃO ARTIFICIAL COM SÊMEN DE DOADOR ANÔNIMO
}

\author{
Sheila Spode* \\ Tatiana Vanessa Saccol da Silva**
}

\begin{abstract}
RESUMO: A paternidade biológica advinda da inseminação artificial heteróloga não deve ser confundida com a paternidade socioafetiva. Esta, construída através de laços de carinho, amor e atenção, prevalece sobre aquela. Ao tratar-se da geração de um filho através de procedimento efetuado com sêmen proveniente de um doador anônimo, deve-se saber que este não possui nenhuma relação, a não ser congênita, com o concebido. Portanto, o doador do sêmen não pode ser considerado "pai", na atual conotação do termo, eximindo-se da obrigação de prestar alimentos ou até mesmo de conceder afeto ao indivíduo gerado a partir do seu material genético. No entanto, o concebido tem o direito de conhecer sua origem biológica paterna, mesmo a título de curiosidade, pois, de forma contrária, teria sua personalidade e autodeterminação atingidas, o que contrariaria princípio fundamental do Direito. Ademais, as probabilidades de relações incestuosas entre irmãos ou entre pai/doador e filha, da mesma forma, laboram para uma conclusão favorável à quebra do anonimato do indivíduo cedente do material genético masculino.
\end{abstract}

PALAVRAS-CHAVE: Inseminação artificial. Doação anônima de sêmen. Identidade genética. Família monoparental. Socioafetividade. Dignidade da pessoa humana. Conflito de direitos.

ABSTRACT: The biological paternity, happened through artificial insemination does not should be confused with the partner-affective paternity. This, constructed through bows of affection, love and attention, prevails on that one. When the subject is the generation of a son through procedure effected with semen proceeding from an anonymous giver, it must be known that this does not possess any relation with the conceived, except the congenital one. Therefore, the giver of the semen cannot be considered "father", in the current connotation of the term, exempting himself of the obligation to give pension or even to grant affection to the individual generated from his genetic material. However, the conceived one has the right to know its biological origin paternal, exactly for a reason or purpose curiosity. Of contrary form, he would have his personality and self-determination reached, fact that would oppose basic principle of the Right. Moreover, the probabilities of incestuous relations between brothers or father/giver and son contribute for a conclusion favorable to the end of the anonymity of the individual assignor of the masculine genetic material.

KEYWORDS: Artificial insemination. anonymous semen donation. genetic identity. Family. Affectivity. Dignity of the person human being. Conflict of rights. 


\section{INTRODUÇÃO}

$\mathrm{O}$ avanço científico possibilitou o surgimento de técnicas que viabilizam a reprodução humana por meios diversos da cópula genital. Tais técnicas constituem espécies da chamada inseminação artificial, ou reprodução assistida. Alterando a natureza da reprodução entre seres humanos, indubitável que a inseminação artificial acabou por trazer mudanças também no mundo sócio-jurídico. Nesse contexto, a principal problemática que decorre da possibilidade da concepção de um ser humano a partir de meios que afastam o elemento volitivo do homem doador do sêmen, no sentido de querer ser "pai", reveste-se na pergunta: uma pessoa gerada por inseminação artificial realizada com sêmen de doador anônimo tem o direito de conhecer a sua origem biológica paterna?

Por outro lado, tem-se que a privação do filho de conhecer sua descendência genética, direito esse que é derivado do princípio basilar da dignidade da pessoa humana, acarretaria em outras celeumas: e se acaso ocorressem relações incestuosas entre irmãos, filhos de mães diferentes, mas que utilizaram o sêmen do mesmo doador? Ou até mesmo entre pai/doador e filha? A diversidade de conseqüências surgidas a partir de uma concepção advinda de inseminação artificial heteróloga leva a questionar se o sigilo das informações decorrentes da doação do sêmen é a melhor maneira de se encarar o processo de pós-concepção do indivíduo.

Está-se diante, portanto, do choque entre o direito do concebido em conhecer a sua origem genética e o direito da manutenção do anonimato por parte do doador.

No momento da doação do material genético, o doador tinha-se por descompromissado de qualquer espécie de vínculo com a mãe ou com o concebido, encarando o processo apenas como um agente auxiliador na concretização do desejo de uma mulher em conceber um filho sem a presença de uma figura paterna, ou, ainda, com o intuito de ajudar em problemas de fertilidade.

Discute-se, então, se pode haver alguma relação de paternidade do doador do sêmen para com o concebido, excluída a biológica. Da mesma forma, indaga-se se é possível mencionar sobre a concessão de qualquer espécie de alimentos pelo doador ou se pode-se exigir, inclusive, afeto do pai biológico por parte do filho ou vice-versa.

Diante da contraposição de direitos apresentada, o trabalho discorrerá na tentativa de estabelecer a prevalência que parece mais cabível aos olhos da razoabilidade sem que para isso se viole o princípio da dignidade da pessoa humana. 


\section{A INSEMINAÇÃO ARTIFICIAL HETERÓlOGA COMO MEIO DE FORMAÇÃO DA FAMÍLIA MONOPARENTAL E O ATUAL TRATAMENTO NORMATIVO DO TEMA}

O avanço científico e tecnológico é grande influenciador das mutações sociais, as quais, em sua maioria, estão à frente do legislador positivo. Em relação à família, núcleo da sociedade e base do desenvolvimento social de todo ser humano, observa-se que a Ciência tem causado verdadeira revolução em antigos conceitos jurídicos. A clássica família patriarcal, selada por laços matrimoniais e amparada na consangüinidade, já não subsiste como única espécie de formação familiar. Avançadas técnicas científicas relacionadas à reprodução humana proporcionaram a diversidade social e jurídica da família, principalmente através da chamada "inseminação artificial".

A inseminação artificial caracteriza-se pela técnica que possibilita a introdução de esperma no interior do canal genital feminino, por processos mecânicos, sem que tenha havido atos sexuais. Ou ainda, com a retirada do óvulo do corpo feminino para fim de se implantar o esperma em laboratório e, posteriormente, reintroduzi-lo no aparelho reprodutor feminino com o intuito de gerar uma nova vida. A inseminação artificial pode ser heteróloga, na qual a mulher encontra em um banco de sêmen um doador anônimo do material genético masculino; e homóloga, na qual o doador do sêmen é o próprio marido ou companheiro. O presente trabalho limita-se à análise da técnica heteróloga, já que dela surgem algumas controvérsias jurídicas, pouco discutidas nos bancos acadêmicos, mas de relevante interesse social.

Diante do que constitui a inseminação artificial heteróloga, ou reprodução assistida heteróloga, evidencia-se que, além de surgir como auxílio na solução de problemas relacionados à fertilidade humana, permite a ocorrência da fecundação a partir do material genético de um terceiro anônimo. Em outras palavras, a reprodução assistida em estudo proporciona a criação e educação de um filho exclusivamente pela genitora, sem o auxílio de uma figura paterna, surgindo, a partir de então, uma nova espécie de família, cuja composição é formada apenas pela mãe e pela prole.

No universo científico, a inseminação não enseja maiores dúvidas. No entanto, tal afirmação não condiz com a realidade jurídica e social que reveste o tema. $O$ ordenamento jurídico brasileiro não dispõe sobre algumas questões pontuais que emanam de uma análise mais apurada do assunto. Diante de uma família monoparental, formada a partir de inseminação heteróloga, como explicar a uma criança ser irrelevante a sua origem biológica paterna? $\mathrm{O}$ indivíduo tem ou não direito de, ao menos, saber 
quem é o seu pai biológico? Ou, no caso de a mãe passar a não possuir condições de sustentar sozinha a família, é direito da prole exigir ajuda alimentar do doador do sêmen?

A resposta para essas questões está no projeto de lei 90/99, especificamente em seu art. $8^{\circ}$, o qual visa impedir que doadores e beneficiários venham a conhecer reciprocamente suas identidades e prima pelo sigilo das informações sobre a criança nascida a partir do material doado. Assim, de acordo com o projeto legislativo, o doador do sêmen jamais poderá ser chamado a auxiliar materialmente o filho biológico e viceversa, ou seja, não há que se falar em obrigação ou dever alimentar entre o doador e o concebido. Da mesma forma, a relação afetiva torna-se inexistente, tendo em vista que a legislação opta pelo sigilo das informações, impedindo que as partes conheçam suas identidades reciprocamente.

Nesse sentido, a Resolução ${ }^{\circ} 1358 / 92$ do Conselho Federal de Medicina igualmente assegura, além da gratuidade do material genético doado, o anonimato do doador, ao enunciar que o sigilo do nome dos doadores e receptores é obrigatório e que as informações sobre pacientes e doadores pertencem, exclusivamente, às clínicas ou centros que mantêm serviços de reprodução assistida. ${ }^{1}$

A técnica da inseminação artificial aparece como uma via alternativa para as mulheres que, em virtude de sua estabilidade econômica ou por outros motivos, optam pela formação de uma família desprovida da figura paterna. Segundo Guilherme Calmon Nogueira $\mathrm{Gama}^{2}$, a própria Constituição Federal reconhece a família monoparental em seu art. 226, parágrafo $4^{\circ}$. Para o autor, a lei brasileira permite a adoção de crianças apenas pelo pai ou pela mãe, fato que deve ser equiparado às mulheres que desejam constituir uma família destituída de um pai, através da inseminação artificial heteróloga. Ademais, a idéia de filiação exclusivamente consangüínea vem sendo progressivamente desmistificada, passando o afeto a ser considerado o elemento primordial para a constituição do núcleo familiar, preponderando-se, inclusive, sobre o "sangue".

\section{A EVOLUÇÃo da IDÉIA dE FAMílIA CONSANGÜÍNEA PARA A DE FAMÍLIA SÓCIO-AFETIVA}

\footnotetext{
${ }^{1}$ JUNIOR, Jesualdo Eduardo de Almeida. Técnicas de reprodução assistida e o biodireito. In: http://jus2.uol.com.br/doutrina/texto.asp?id=6522. ${ }^{2}$ GAMA, Guilherme Calmon Nogueira. Filiação e Reprodução Assistida: Introdução ao tema sob a perspectiva do direito comparado. Revista Brasileira de Direito de Família, 2000, p.22/23.
} 
O afeto não é fruto da biologia ${ }^{3}$. A contrario sensu, o fato de duas pessoas possuírem a mesma descendência genética não é sinônimo de que ambas possuirão laços de afetividade. Cada vez mais, portanto, a sociedade contemporânea atribui um valor maior ao aspecto sócio-afetivo como determinador da filiação em detrimento do fator genético.

No âmbito social, o princípio da afetividade está em plena ascensão, derrubando antigos preconceitos e desenvolvendo políticas de incentivo à adoção que demonstram a importância do elo emocional entre pais e filhos. É exatamente essa nova noção de família, baseada nos laços de afeto, a principal responsável pela transposição de antigos tabus e preconceitos que diferenciavam e afastavam as pessoas que não se enquadravam no estereótipo de família consangüínea. Nesse contexto, uma vez superada a idéia de que o critério consangüíneo era o único a determinar o núcleo familiar, tornou-se plenamente possível a formação de famílias por homossexuais, chamadas de homoafetivas, ou mesmo pela presença de somente um dos genitores, conhecidas como famílias monoparentais. Deixou-se de lado, portanto, a carga genética como elemento cerne da família, assumindo o seu lugar os fatores determinantes da afetividade e da solidariedade.

Evidentemente, todas essas mudanças ocorridas no contexto social contemporâneo exigiram do legislador um esforço especial, a fim de trazer as novas realidades familiares para o universo jurídico. O Direito passou, também, a enxergar a filiação com os olhos da afetividade, tratando todos os filhos de forma igualitária, sem distingui-los em legítimos (sanguíneos) e ilegítimos (adotivos), como ocorria antigamente. Prova dessa revolução jurídica foram as alterações realizadas no ordenamento, principalmente a partir da Constituição Federal de 1988, a fim de equiparar os direitos decorrentes da filiação adotiva aos da filiação genética.

$\mathrm{O}$ art. $227, \S 6^{\circ}$, contém importante norma relativa ao direito de filiação, reconhecendo igualdade de direitos e qualificações aos filhos, havidos ou não da relação de casamento, ou por adoção, proibidas quaisquer designações discriminatórias a ela relativas. Ficam, assim, banidas da legislação civil expressões como filhos legítimos, filhos naturais, filhos adulterinos, filhos incestuosos ${ }^{4}$.

Embora o Código Civil não faça menção expressa à palavra "afeto", ressalta a ilustre professora Maria Berenice Dias que o mesmo traz essa conotação implícita em

\footnotetext{
${ }_{3}^{3}$ DIAS. Maria Berenice. Manual de Direito das Famílias. Editora Revista dos Tribunais. $3^{\text {a }}$ Edição. São Paulo. 2006.

${ }^{4}$ SILVA, José Afonso. Curso de Direito Constitucional. Malheiros Editores. 24a Edição. São Paulo. 2005.
} 
grande parte de seus dispositivos concernentes ao Direito de Família, tal como se verifica no artigo 1584, parágrafo único. Essa mesma autora é revolucionária ao enfatizar que:

A filiação socioafetiva assenta-se no reconhecimento da posse de estado de filho: a crença da condição de filho fundada em laços de afeto. A posse do estado é a expressão mais exuberante do parentesco psicológico, da filiação afetiva. A afeição tem valor jurídico. A paternidade e a maternidade biológica nada valem frente ao vínculo afetivo que se forma entre a criança e aquele que trata e cuida dela, lhe dá amor e participa da sua vida. ${ }^{5}$

No caso em estudo, impossível parece se falar em afeto entre filho e genitor pela razão óbvia de que o anonimato do último não permite a sua ocorrência. Assim, se a atual idéia de família está baseada preponderantemente no afeto, sua conseqüência lógica é a de que o doador anônimo do material utilizado na inseminação artificial não pode ser considerado "pai" do concebido, mas apenas seu genitor, eis que inexistente qualquer relação fraterna ou emocional entre ambos.

Evidentemente, essa inexistência de uma relação de parentesco entre ambos desincumbe o genitor de arcar com qualquer ônus decorrente da relação parental. Afinal, no momento em que o genitor dispõe de seu sêmen, realiza a mesma operação daquele que doa um filho, sendo-lhe destituído qualquer poder de ingerência sobre a vida do menor, bem como o desincumbindo de todos os encargos decorrentes da filiação. Dessa forma, parece notório que o filho jamais poderá exigir prestação alimentícia ou qualquer outra ajuda de cunho pecuniário daquele que lhe forneceu o material genético, caso algum dia venha a encontrá-lo, da mesma forma que o filho doado não pode exigir qualquer contribuição do seu pai biológico.

Outro não poderia ser o entendimento acerca da ausência de necessidade do genitor prestar auxílio moral, fraterno, emocional ao filho concebido pela técnica da fertilização heteróloga. Evidentemente, se o pai biológico preferiu doar anonimamente seu material genético é porque não possui interesse em arcar com o encargo emocional decorrente da condição de "pai", de forma que inviável parece impor-lhe esse ônus, o qual é exatamente o fator determinante para que ele se utilize do anonimato para doar.

Pode-se concluir, portanto, que os deveres alimentares e fraternais não caracterizam argumento suficiente para se afastar o anonimato do doador vez que, em consonância com o atual entendimento doutrinário, a condição de pai não é caracterizada pelo aspecto genético que vincula os indivíduos, mas sim pelo aspecto

\footnotetext{
${ }^{5}$ DIAS, Maria Berenice. Manual de Direito das Famílias. Editora Revista dos Tribunais. $3^{\text {a }}$ Edição. São Paulo. 2006.
} 
afetivo que os une voluntariamente, de forma que o doador jamais poderia ser compelido a contribuir econômica ou emocionalmente para a manutenção do filho.

Ocorre, no entanto, que, embora a questão biológica não seja mais o único fator a determinar as relações de filiação, há casos em que ele ainda surge com certa força, principalmente quando é do interesse da criança conhecer os seus verdadeiros genitores. Assim ocorre no caso em tela, em que a mãe gera o filho através da inseminação do sêmen de um doador anônimo. Por mais que o doador do material genético não seja considerado "pai” na atual concepção sócio-jurídica do termo, não se pode afirmar que tal condição lhe dê o direito de garantir por completo o seu anonimato, de forma a afastar o direito da criança de conhecer sua origem genética.

E se a criança tiver interesse em conhecer o pai? Pode o sigilo das informações, o direito ao anonimato do doador, pretensamente garantidos pelo projeto de Lei 90/99, serem quebrados? Verifica-se que, principalmente nesse tipo específico de procriação, a questão biológica ganha conotações maiores e assume papel decisivo, embora venha sendo cada vez mais afastada do universo jurídico e social. Assim, embora se constate a importância do fator afetivo em face do biológico para definição da paternidade, não há como afirmar que este último deve ser absolutamente desconsiderado quando se analisa a questão sob o ângulo do direito do concebido de conhecer sua origem biológica.

\section{A QUEBRA DO SIGILO DAS INFORMAÇÕES EM VIRTUDE DO DIREITO FUNDAMENTAL À IDENTIDADE GENÉTICA}

É pacífico o entendimento que "pai” é aquele que presta auxílio material e emocional ao filho, independentemente de possuírem o mesmo sangue. É pacífico, também, que a mãe que se submete a receber sêmen de um doador anônimo arca com todas as responsabilidades sobre a criança, afastando a figura paterna do doador. Analisando-se, portanto, o assunto sob o aspecto do pai ou da mãe, parece não haver controvérsias.

Mas quando o foco passa a ser o filho gerado a partir do referido procedimento, a questão ganha outras dimensões. Em face da atual concepção jurídica de paternidade socioafetiva, parece simples concluir que o concebido não possui qualquer relação de filiação com o doador do material. Entretanto, pode-se entender que tal afirmação é argumento suficiente para obstaculizar o direito ao conhecimento da origem biológica por parte do filho? 
A resposta a essa celeuma está na análise do direito que se sobressai: o direito ao anonimato ou o direito à identidade genética, representado pelo conhecimento da origem biológica.

$\mathrm{O}$ direito ao anonimato do doador de material genético utilizado em inseminação heteróloga decorre de motivações altruístas de um indivíduo do sexo masculino a fim de auxiliar mulheres que, por variadas razões, desejam conceber um filho sem a participação da figura paterna. Não há, portanto, interesse do doador em ser pai, mas tão somente em agir solidariamente ao próximo. É exatamente essa ausência de desejo paterno que faz com que o doador opte pelo anonimato, desincumbindo-se, desse modo, de todos os encargos decorrentes da paternidade.

Já o direito à identidade genética é de maior complexidade vez que possui uma série de consequiências sociais e jurídicas que precisam ser minuciosamente discutidas antes de se chegar a alguma conclusão.

Define-se o direito à identidade genética como a prerrogativa de todo cidadão de, independentemente de possuir um "pai", conhecer o seu verdadeiro genitor, ou seja, ter acesso à sua origem genética. $\mathrm{O}$ direito à identidade genética é direito fundamental de todo ser humano, caracterizando-se por ser personalíssimo, indisponível e intransferível. Tal caráter personalíssimo faz com que o seu exercício seja de prerrogativa exclusiva do indivíduo concebido, de forma que não pode ser obstaculizado por parte do pai ou da mãe, e tão menos pela própria Lei.

Dessa forma, não parece plausível que o Projeto de Lei 90/99 imponha o caráter obrigatório do sigilo da identidade do doador se é direito do concebido escolher se quer ter acesso à sua qualidade genética ou não.

Trata-se, em verdade, da sobreposição do princípio constitucional da dignidade da pessoa humana, o qual torna inviável a manutenção de um sigilo passível de prejudicar a formação do concebido como indivíduo. Afinal, restringindo-se o direito de conhecer sua origem genética, está-se negando a uma pessoa a possibilidade de ter acesso a informações que possam auxiliar na descoberta de fatores que compõem a sua personalidade e que influenciam na sua autodeterminação.

O princípio da dignidade da pessoa humana está assegurado como direito fundamental no art. $1^{\circ}$, inciso III, da Constituição Federal e é definido pelo autor Alexandre de Moraes como sendo:

Um valor espiritual e moral inerente à pessoa, que se manifesta singularmente na autodeterminação consciente e responsável da própria vida e que traz consigo a 
pretensão ao respeito por parte das demais pessoas, constituindo-se um mínimo invulnerável que todo estatuto jurídico deve assegurar. ${ }^{6}$

Assegurar ao concebido o direito à dignidade pressupõe reconhecer seu legítimo direito de saber a verdade sobre sua identidade genética, independentemente da existência de paternidade afetiva. É nesse contexto que se insere o caso no qual a mãe recebe o sêmen de um doador anônimo. Ficando este legalmente protegido em face do sigilo das informações, estar-se-ia obstaculizando a efetivação do direito fundamental do concebido de identificar sua descendência genética.

Não há como aceitar que uma norma individualizadora, que impede o conhecimento por parte do indivíduo sobre sua origem, se sobreponha a um preceito constitucional fundamental, de grande importância para o alcance dos objetivos sociais previstos na constituição.

Ressalte-se que o próprio projeto de lei 90/99, que trata do assunto e garante o anonimato do doador, expõe uma ressalva a esse anonimato quando a vida ou a saúde do concebido exigirem a obtenção das informações acerca da paternidade. Observa-se, entretanto, que o direito à identidade genética não se restringe à hipótese prevista no projeto de lei, decorrente de problemas de saúde, abordando também outras razões possíveis para que o anonimato não se mantenha. Tais razões incluem até mesmo a mera curiosidade do concebido.

Reportagem exibida em programa televisivo da Rede Globo ${ }^{7}$ narrou a história de cinco irmãos de mães diferentes, concebidos por meio de inseminação heteróloga na qual as mães utilizaram um doador anônimo de sêmen. Eles se encontraram através de um site da internet que cruzou os seus DNA's e constatou que possuíam o mesmo pai. Embora morassem em locais totalmente diversos, seu encontro foi possível por meio da internet. Hoje, os cinco irmãos sabem que foram concebidos através do mesmo material genético depositado em um laboratório na Inglaterra e cujo doador possui o número 66.

No caso narrado, embora soubessem que eram irmãos, nenhum deles conhecia o pai biológico já que tal informação estava protegida pela legislação inglesa. Há algum tempo, tal legislação foi modificada, de forma que passou a permitir aos irmãos a pesquisa acerca da sua descendência paterna. Caso o sigilo da informação continuasse sendo priorizado, fato que ocorre no Brasil, péssimas consequiências poderiam daí advir.

\footnotetext{
${ }^{6}$ MORAES, Alexandre de. Direitos Humanos Fundamentais: Teoria Geral, Comentários aos arts. $1^{\circ}$ a $5^{\circ}$ da Constituição da República Federativa do Brasil, Doutrina e Jusrisprudência.Editora Atlas. 6ª Edição. São Paulo. 2005.

${ }^{7}$ Programa Jornalístico Fantástico. Data de 11.12.2005. in: www.globo.com/fantastico
} 
Uma das possíveis consequiências seria a hipótese da manutenção de relações incestuosas entre esses irmãos, ou mesmo entre pai/doador e filha, sem que os mesmos soubessem da sua consangüinidade. Ressalte-se que, quanto à ocorrência de relações amorosas entre o concebido e o doador, pode-se aplicar analogicamente a norma prevista no art. 1626 do Código Civil, que pró́be o casamento entre os pais consangüíneos e os adotados.

Embora os laboratórios aleguem que procuram ceder o material para diferentes regiões, dificultando que o pai e os irmãos se encontrem, tal argumento não se mostra mais apto a impedir que isso ocorra em face da progressiva quebra de fronteiras promovida pelo avanço tecnológico e pela internet. Prova disso é o caso narrado dos cinco irmãos que se encontraram.

Frente à demonstrada inconstitucionalidade do Projeto de Lei 90/99, que se torna desde logo uma norma natimorta, a idéia inicial de que o doador está indiscutivelmente protegido pelo anonimato não mais deve se manter, cedendo lugar ao direito do concebido de conhecer a sua origem genética. Ressalte-se, entretanto, que tal entendimento não conduz à conclusão de que o doador possa ser considerado "pai" do concebido, seja para auxílio alimentar, seja para auxílio fraterno. Afinal, a partir do momento em que ele doa o seu material genético, realiza o mesmo ato do pai que doa o filho já concebido, perdendo todo o poder de guarda sobre ele.

Essa interpretação afasta o temor dos laboratórios de que, uma vez derrubado o sigilo das informações, ninguém mais se disponibilizaria a ceder gratuitamente seu sêmen se pudesse ser chamado posteriormente a sustentar um filho indesejado. A doutrina, de maneira ainda tímida, vem coadunando com esse entendimento, concluindo que o acesso às informações do doador não gera o dever deste de sustentar o filho:

A criança somente será registrada em nome da mãe, mas poderá no futuro requerer o reconhecimento de seu vínculo de filiação biológica sem que isto acarrete ao doador quaisquer obrigações ou direitos relativos à criança, uma vez que ao doar seu sêmen ele abdica voluntariamente de sua paternidade da mesma forma que o faz quem entrega uma criança para adoção. ${ }^{8}$

Assim, embora o direito ao anonimato da doação seja capaz de afastar a responsabilidade do genitor quanto ao sustento material e afetivo do concebido, tal não tem o condão de afastar o direito deste de, sempre que possuir interesse, obter informações acerca da sua descendência genética paterna.

${ }^{8}$ FILHO, José Roberto Moreira. "O direito civil em face das novas técnicas de reprodução assistida". In: http://www.bioconsulte.bio.br/textos/direitocivil.pdf 


\section{CONSIDERAÇÕES FINAIS}

A atual postura da doutrina e jurisprudência firma-se no sentido de que "pai" é aquele que educa, dá carinho, isto é, aquele que mantém uma relação socioafetiva com o filho, de forma que, cada vez mais, a paternidade biológica vem perdendo terreno. Nesse contexto, parece evidente que o doador de material genético utilizado em inseminação artificial heteróloga não pode ser chamado a contribuir para o sustento do concebido ou mesmo a prestar-lhe qualquer apoio emocional, já que inexiste relação socioafetiva entre ambos.

Mas, por outro lado, o aspecto biológico que reveste as relações familiares não pode ser totalmente desconsiderado, máxime no caso em estudo em que a identidade genética do concebido resta por ele absolutamente desconhecida. Verifica-se, portanto, que o direito ao anonimato do doador vai de encontro ao direito de qualquer ser humano de ter acesso à sua origem genética.

Embora o direito ao anonimato firme-se no argumento de que aquele que doa o seu sêmen age tão somente com objetivo solidário, a fim de auxiliar outra pessoa que deseja conceber um filho, tal não prevalece diante da prerrogativa do concebido de ter acesso à sua identidade genética. Isso ocorre vez que o direito ao conhecimento da origem genética possui raízes mais profundas e se baseia no princípio basilar e fundamental da dignidade da pessoa humana. Afinal, é direito de qualquer ser humano ter acesso à sua identidade genética, como forma de conhecer elementos importantes formadores da sua personalidade e da sua autodeterminação.

Além do referido princípio, outros fatores também primam pela supremacia do direito à identidade genética, de forma a determinar a relativização do sigilo das informações. Cite-se, por exemplo, a probabilidade da existência de relações incestuosas entre irmãos ou entre pai/doador e filha, que desconhecem seus laços consangüíneos. Afinal, em um mundo em que o progresso tecnológico tornou irrisórias as distâncias, não há como impossibilitar que irmãos ou, até mesmo, pai e filha se conheçam.

Assegurar, portanto, ao concebido o direito ao conhecimento da sua identidade genética pressupõe garantir a sua dignidade como ser humano. Dessa forma, não há como prevalecer no ordenamento jurídico o sigilo das informações daquele que doa material genético para fins de inseminação artificial, seja pela supremacia do princípio da dignidade da pessoa humana, preceito constitucional formador dos objetivos sociais 
pátrios; seja por questões de ordem prática que demonstram a incongruência do anonimato com o universo jurídico e social atual.

\section{REFERÊNCIAS BIBLIOGRÁFICAS}

BRASIL. Constituição da República Federativa do Brasil: promulgada em 05 de outubro de 1988. Atualizada até a Emenda Constitucional n 53, de 19/12/2006. 9a ed. São Paulo: Revista dos Tribunais, 2007.

DIAS, Maria Berenice. Manual de Direito das Famílias. $3^{\text {a }}$ ed. São Paulo: Revista dos Tribunais, 2006.

FILHO, José Roberto Moreira. O direito civil em face das novas técnicas de reprodução assistida. In: http://www.bioconsulte.bio.br/textos/direitocivil.pdf.

GAMA, Guilherme Calmon Nogueira. Filiação e Reprodução Assistida: Introdução ao tema sob a perspectiva do direito comparado. Revista Brasileira de Direito de Família. 2000.

JUNIOR, Jesualdo Eduardo de Almeida. Técnicas de reprodução assistida e o biodireito. In: http://jus2.uol.com.br/doutrina/texto.asp?id=6522.

MORAES, Alexandre de. Direitos Humanos Fundamentais: Teoria Geral, Comentários aos arts. $1^{\circ}$ a $5^{\circ}$ da Constituição da República Federativa do Brasil, Doutrina e Jusrisprudência. $6^{a}$ ed. São Paulo: Atlas, 2005.

RIZZARDO, Arnaldo. Direito de Família. 4ª ed. São Paulo: Forense, 2006.

SILVA, José Afonso. Curso de Direito Constitucional. 24a ed. São Paulo: Malheiros, 2005.

VENOSA, Sílvio de Salvo. Direito Civil - Direito de Família. São Paulo: Atlas, 2001.

WALD, Arnoldo. O Novo Direito de Família. 15 ed. São Paulo: Saraiva, 2004. 